\title{
IMPROVEMENT OF QUALITY AND YIELD OF GREENHOUSE TOMATO (SOLANUM LYCOPERSICUM L.) PLANTS BY MICRO- SPRINKLER IRRIGATION UNDER PLASTIC FILM
}

\author{
ZHANG, M. Z. $.^{1,2,3}-$ NIU, W. Q. ${ }^{4,5,6}-$ BAI, Q. J. ${ }^{1 *}-$ LI, Y. ${ }^{3}-$ WANG, J. W. ${ }^{7}-$ WANG, Z. Q. ${ }^{8}-$ \\ ZHANG, Z.X..$^{9,10}$
}

${ }^{1}$ State Key Laboratory of Eco-hydraulics in Northwest Arid Region of China, Xi'an University of Technology, Xi'an 710048, Shaanxi, China

${ }^{2}$ Henan Provincial Water Conservancy Research Institute, Zhengzhou 450000, China

${ }^{3}$ Northwest Land and Resources Research Center, Shaanxi Normal University, Xi'an 710119, Shaanxi, China

${ }^{4}$ Institute of Soil and Water Conservation, Northwest A\&F University, Yangling 712100, Shaanxi, China

${ }^{5}$ Institute of Water-saving Agriculture in Arid Areas of China (IWSA), Northwest A\&F University, Yangling 712100, Shaanxi, China

${ }^{6}$ Institute of Soil and Water Conservation, Chinese Academy of Sciences \& Ministry of Water Resources, Yangling 712100, Shaanxi, China

${ }^{7}$ College of Resources and Environment, Shanxi University of Finance and Economics, Taiyuan 030006, Shanxi, China

${ }^{8}$ College of Environment Sciences and Engineering, Peking University, Beijing 100871, China

${ }^{9}$ Key Laboratory of Vegetation Ecology, Ministry of Education, Institute of Grassland Science, Northeast Normal University, Changchun, Jilin Province 130024, China

${ }^{10}$ State Environmental Protection Key Laboratory of Wetland Ecology and Vegetation Restoration, School of Environment, Northeast Normal University, Changchun, Jilin Province 130117, China

${ }^{*}$ Corresponding author

e-mail:qjb0206@163.com

(Received $20^{\text {th }}$ May 2020; accepted $14^{\text {th }}$ Aug 2020)

\begin{abstract}
This study clarified the applicability of micro-sprinkler irrigation under plastic film (MSPF) in a greenhouse and finding the optimal micropores group spacing and capillary arrangement density. The effects of different micropores group spacing (L1: $30 \mathrm{~cm}$ micropores group spacing, and L2: $50 \mathrm{~cm}$ micropores group spacing) and capillary arrangement density $(\mathrm{C} 1$ : one pipe for one row, $\mathrm{C} 2$ : one pipe for two rows, and C3: one pipe for three rows) with the MSPF on the growth, quality, yield (Y), and water use efficiency (WUE) of tomato were studied. A completely randomized trial design was used, and drip irrigation under plastic film and micro-sprinkler irrigation were used as controls. The results showed that MSPF in a greenhouse can lead to saving water, increase yield, and improve crop quality. Compared to $50 \mathrm{~cm}$ micropores group spacing, $30 \mathrm{~cm}$ was better for tomato growth and also increased fruit quality, yield, and WUE. Considering our results comprehensively, the combination of one pipe for two rows under a micropores group spacing of $30 \mathrm{~cm}$ is recommended as technical parameters for greenhouse tomato cultivation under MSPF in arid and semi-arid sandy loam soils.
\end{abstract}


Keywords: micropores group spacing, capillary arrangement density, quality, water use efficiency, comprehensive benefit evaluation

Abberviations:

\begin{tabular}{c|c|c}
\hline No & Abbreviations & Full name \\
\hline 1 & L & Micropores group spacing \\
2 & C & Capillary arrangement density \\
3 & PH & Plant height \\
4 & SD & Stem diameter \\
5 & LAI & Leaf area indices \\
6 & SFW & Weight of single fruit \\
7 & VD & Vertical diameters \\
8 & TD & Transverse diameters \\
9 & TSS & Total soluble solids content \\
10 & TSU & Total soluble sugar \\
11 & SSC & Soluble sugar content \\
12 & TA & Titratable acids \\
13 & SAR & Sugar/acid ratio \\
14 & SP & Soluble protein \\
15 & VC & Vitamin C \\
16 & LY & Lycopene \\
17 & Y & Yield \\
18 & WUE & Water use efficiency \\
19 & CRITIC & Criteria importance though intercrieria correlation \\
20 & TOPSIS & Technique for order preference by similarity to an ideal solution \\
\hline
\end{tabular}

\section{Introduction}

The development of facility agriculture has provided a powerful guarantee for vegetable production in arid and semi-arid sandy loam soils of northwest China. However, the irrigation water used for facilitating agriculture in this region mainly originates from groundwater, and the resulting groundwater resource exploitation has exacerbated the water crisis in these arid and semi-arid areas; therefore, it is urgently required to mitigate the excessive use of irrigation water in this region (Du et al., 2014). Therefore, the realization of a more efficient utilization of water resources has become the current research hotspot in this region. As a common irrigation method for the greenhouse tomato (Solanum Lycopersicum L.) in this area, drip irrigation offers the advantages of watersaving, fertilizer-saving, and labor-saving. It has been widely used on tomato, pepper, melon, and other crops (Liu et al., 2012; Zhang et al., 2017; Wang et al., 2018a). Because of the existence of sediment, chemical precipitates, or biomass in the irrigation water body, the emitters in the drip irrigation system clog easily, resulting in decreased irrigation uniformity, accompanied by decreased crop yield and an increased cost (Yu et al., 2010; Feng et al., 2018). Drip irrigation belongs to local irrigation, and the soil wetting body per unit area of tillage layer is limited, which greatly hinders the development of the crop root system (Michelakis et al., 1993; Zhou et al., 2017).

As one of the many development forms of drip irrigation, micro-sprinkler irrigation is an irrigation form, where sprinkler (micro) pores are arranged in groups on the wall of a thin-walled drip irrigation plastic pipe (flat strip after coiling) (Zhang et al., 2009). The emitter energy dissipation structure is removed. Under identical working pressures, the flow velocity of micro-sprinkler irrigation is about 15 times larger than that of labyrinth drip irrigation. This results in strong sediment-carrying capacity and anti-clogging performance of the micro-sprinkler irrigation. This technique can solve the clogging 
problem of drip irrigation emitters (Yu et al., 2010; Feng et al., 2018). At the same time, the flow rate of a single group of micro-sprinklers is much higher than that of drip irrigation, which easily increases the ratio of the horizontal and vertical migration distance of soil moisture peaks, and improves the uniformity of the soil wetting body and the water per unit area of tillage layer (Ould et al., 2001; Del et al., 2020). Micro-sprinkler irrigation offers the advantages of decreasing the restriction of horizontal root growth and short irrigation duration (Man et al., 2014; Li et al., 2019a). Therefore, micro-sprinkler irrigation has been used for winter wheat, summer corn, lawn, seedlings, and other crops, where it has achieved good results (Man et al., 2014; Baram et al., 2018; Fletcher et al., 2018; Li et al., 2018a). However, the shape, area, and uniformity of soil wetting in a micro-sprinkler irrigated area are affected by the wind speed. In addition, problems, such as difficulty to control weeds and high damage rate of micro sprinklers currently obstructs micro-sprinkler irrigation treatment (Man et al., 2014, 2017; Li et al., 2019b).

The development of facility agriculture provides a good environment for the application of micro-sprinkler irrigation, since it offers flat land, no wind indoors, and short capillary laying distance (Tsitsimpelis et al., 2016). However, the space of facility agriculture is relatively closed, and micro-sprinkler irrigation water spray atomization easily increases air humidity. High temperature and high humidity have been shown to facilitate crop diseases and insect pests (Gómez-Rodríguez et al., 2003; Er and Gökçe, 2004; Camara et al., 2017), resulting in less use of micro-sprinkler irrigation in facility agriculture. Plastic film mulching provides a solution for the application of microsprinkler irrigation in facility agriculture. Plastic film mulching can restrain the water jet of micro-sprinkler irrigation, decrease spray water atomization and ineffective water evaporation, and help to improve irrigation water use efficiency (WUE) (Massatbayev et al., 2016; Wang et al., 2019a). Therefore, the combination of micro-sprinkling irrigation and film mulching technology, and the use of multiple groups of small micro-pores beneath the film can compensate for the shortcomings of the micro-spray pipes used in the greenhouse. This technique is called micro-sprinkler irrigation under plastic film (MSPF, Fig. 1). The exploration of MSPF is of great significance to enrich the greenhouse micro-irrigation technology system, expanded the scope of the application of microsprinkler irrigation, and decrease the water needed for crops, and increases both the yield and quality of crops.

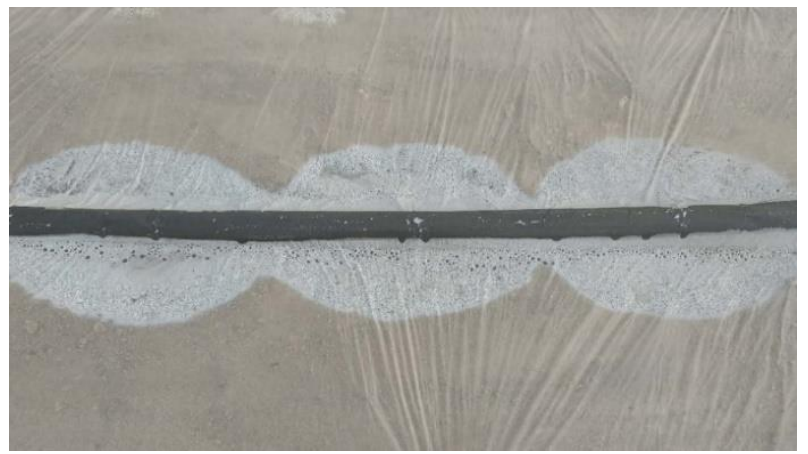

Figure 1. Micro-sprinkler irrigation under plastic film (MSPF)

The tomato is one of the main vegetables grown in facility agriculture in the arid to semi-arid areas of northwest China. The tomato has rich nutritional value and is the main cash crop with which local farmers increase their income (Malherbe and Marais, 2015; 
Liu et al., 2019). The greenhouse tomato in this area belongs to sparse planting crops. Based on its unique planting structure pattern, the selection and arrangement of orifice flow directly changes the soil water distribution and indirectly affects the WUE and investment cost of tomato plants. The orifice flow position on the capillary pipe (i.e., dripper spacing) and the orifice flow position between the capillary pipe (i.e., capillary arrangement density) are two aspects of the orifice flow position. Therefore, for the sustainable development of the greenhouse tomato industry in this region, it is important to determine the optimal position of the orifice flow position on the capillary pipe and the orifice flow position between the capillary pipe. These values will enable the best balance between increasing production and improving quality while reducing the use of irrigation water. Previous studies on drip irrigation showed that the confluence time of the wetting peaks at two adjacent dippers was shorter at identical dipper flow rate. Moreover, the surface wetting shape of soil moisture under two adjacent emitters was approximately rectangular when the emitter spacing decreased from 80 to $30 \mathrm{~cm}$ (Ould et al., 2001; Elmaloglou and Diamantopoulos, 2010). The more uniform the wetting body was, the more irrigation water use could be decreased and irrigation WUE increased (Xu et al., 2012; Sui et al., 2018). When the dipper spacing increased from 15 to $30 \mathrm{~cm}$, the yield of onions first increased and then decreased (Enciso et al., 2007). The smaller the capillary arrangement density is, the more uniform the horizontal water content distribution will be, and the higher the crop dry matter accumulation and yield will be. However, the higher capillary arrangement density easily increases the investment cost. This is also not conducive for the improvement of vegetable flavor, nutrition, and WUE (Bozkurt et al., 2006; Chen et al., 2015; Zhou et al., 2017; Liu et al., 2019; Lv et al., 2019; Yang et al., 2019).

At present, relevant research mainly focused on the orifice flow position on the capillary pipe (i.e., dripper spacing) and the orifice flow position between the capillary pipe (i.e., capillary arrangement density) in the drip irrigation capillary with small flow. However, few studies investigated the influence of the change of the orifice flow position on the capillary pipe (i.e., micropores group spacing) and orifice flow position between the capillary pipe (i.e., capillary arrangement density) on greenhouse crops using MSPF. In production practice, yield is the goal pursued by farmers, quality is the demand of users, and WUE is the core of the effective utilization of agricultural water resources (Wang et al., 2019b). Sufficient soil moisture can increase yield, but fruit quality and crop WUE will both decrease, while profit loss will increase when too much water is used (Luo and $\mathrm{Li}, 2018)$. It remains difficult to optimize quality, yield, and WUE. The technique for order preference by similarity to an ideal solution (TOPSIS) method provides a solution for multi-objective decision-making optimization. It has been widely used to comprehensively evaluate both the advantages and disadvantages of the tomato irrigation system. Luo and Li (2018) takes tomato yield, quality and water use efficiency as evaluation indexes, uses principal component standard deviation method to obtain each index weight, and establishes a comprehensive evaluation model based on weighted TOPSIS combination to select the best irrigation mode and irrigation quantity. Liu et al. (2019) used the yield, quality, and WUE of tomato as evaluation index, where the weight of each index was made equal to 1 by an artificial method. A comprehensive evaluation model based on weighted TOPSIS combination was established to optimize the best irrigation frequency and irrigation quantity. At present, the TOPSIS method is relatively rarely applied for comprehensive benefit evaluations of MSPF. 
Therefore, compared with drip irrigation and micro-sprinkler irrigation, this study explored the applicability of MSPF in the greenhouse. The responses of tomato growth, quality, yield, and WUE to different micropores group spacing and capillary arrangement density were investigated. In addition, a comprehensive benefit evaluation model of greenhouse tomato quality, yield, and WUE was established by the TOPSIS method to optimize different treatments. The combination model of micropore spacing and capillary arrangement density was obtained for the best quality, yield, and WUE of tomato plants under MSPF. This paper enriched the data on tomato micro-irrigation technology systems in arid and semi-arid sandy loam soil of facility agriculture. Data support and a theoretical basis are provided for water-saving, yield increases, and improved quality of facility agricultural crops in this area by using greenhouse experiments and multi-objective optimization data analysis.

\section{Materials and methods}

\section{Experimental site and management}

The experiment was conducted from March 27, 2019, to July 23, 2019, in a greenhouse at the Modern Agricultural Science and Technology Exhibition Center of Xi'an City, Shaanxi Province, China $\left(108^{\circ} 52^{\circ} \mathrm{E}, 34^{\circ} 03^{\circ} \mathrm{N}\right)$. It has a warm temperate semi-humid continental monsoon climate. The soil is sandy loam, and the mass fractions of sand, silt, and clay are $63.9 \%, 29.63 \%$, and $6.47 \%$, respectively. The average bulk density of the $1.0 \mathrm{~m}$ soil layer was $1.48 \mathrm{~g} / \mathrm{cm}^{3}$, the water holding capacity of field weight was $27.40 \%$, and the depth of groundwater table on the site exceeded $30 \mathrm{~m}$. The content of organic matter, total phosphorus $(\mathrm{P})$, total potassium $(\mathrm{K})$, total nitrogen, available nitrogen, available $\mathrm{P}$, and available $\mathrm{K}$ in the plough layer before sowing were $15.53 \mathrm{~g} / \mathrm{kg}$, $10.12 \mathrm{~g} / \mathrm{kg}, 2.01 \mathrm{~g} / \mathrm{kg}, 1.36 \mathrm{~g} / \mathrm{kg}, 70.45 \mathrm{mg} / \mathrm{kg}, 112 \mathrm{mg} / \mathrm{kg}$, and $85.23 \mathrm{mg} / \mathrm{kg}$, respectively. The irrigation water originated from groundwater, the $\mathrm{pH}$ of which was 6.8 , the chemical oxygen demand (COD) was $53.2 \mathrm{mg} / \mathrm{L}$, the anionic surfactant content was $3.2 \mathrm{mg} / \mathrm{L}$, and the chloride content was $0.48 \mathrm{mg} / \mathrm{L}$.

The greenhouse ( $85 \mathrm{~m}$ long and $15 \mathrm{~m}$ wide) was oriented from north to south. The tomato variety 'Jingfan 401' (Jingyan Yinong Seed Sci-tech Co. Ltd., Beijing, China), with a $50 \mathrm{~cm}$ row spacing and a $40 \mathrm{~cm}$ plant spacing, was planted on a ridge. The length of the ridge was $3.4 \mathrm{~m}$ and the width was $1.2 \mathrm{~m}$. The irrigation plot is shown in Fig. 2 . The distance between each plot was $4 \mathrm{~m}$; one 1.0-m deep building waterproof film made up of styrene-butadiene-styrene block copolymer was buried in the middle to prevent the horizontal infiltration and movement of soil moisture, thus avoiding their effect on other plot experiments. Tomato plants were topped when the four-eared fruit were retained and the field management measures, such as fertilisation, irrigation, and pesticides, were kept similar in all treatments. The source of irrigation water in the region was groundwater. To ensure the survival of seedlings on the day of planting, the irrigation was unified with reference to the local tomato planting experience. Spring tomatoes were planted on 27 March 2019 and irrigation treatment was initiated on 4 April 2019. The irrigation treatment was continued until 15 July 2019 and tomatoes were completely harvested on 25 July 2019. Autumn tomatoes were planted on 23 August 2019, irrigation treatment was continued between 30 August 2019 and 17 January 2020, and tomatoes were complete harvested on 30 January 2020. The micro-sprinkler pipe of MSPF (Hebei Plentirain Irrigation Equipment Technology Co., Ltd., Hebei, China) adopts three thinwalled oblique micropores with a diameter of $32 \mathrm{~mm}$ and a micropore diameter of $0.8 \mathrm{~mm}$. 
The micropores group spacing is shown in the experimental design (Table 1 and Fig. 3). Drip irrigation under mulch (CK1, Hebei Plentirain Irrigation Equipment Technology Co., Ltd., Hebei, China) with thin-walled labyrinth tooth channel was selected as control. The geometric parameters of the channel were $54.3 \times 1.1 \times 0.83 \mathrm{~mm}$, the distance between emitters was $30 \mathrm{~cm}$, and the emitter flow rate was $2 \mathrm{~L} / \mathrm{h}$. Micro-sprinkler irrigation $(\mathrm{CK} 2$, Hebei Plentirain Irrigation Equipment Technology Co. Ltd, Hebei, China) adopted three thin-walled oblique micropore pipes with a diameter of $32 \mathrm{~mm}$ and a micropore diameter of $0.8 \mathrm{~mm}$ an was also used as control. The micropores group spacing was $10 \mathrm{~cm}$.

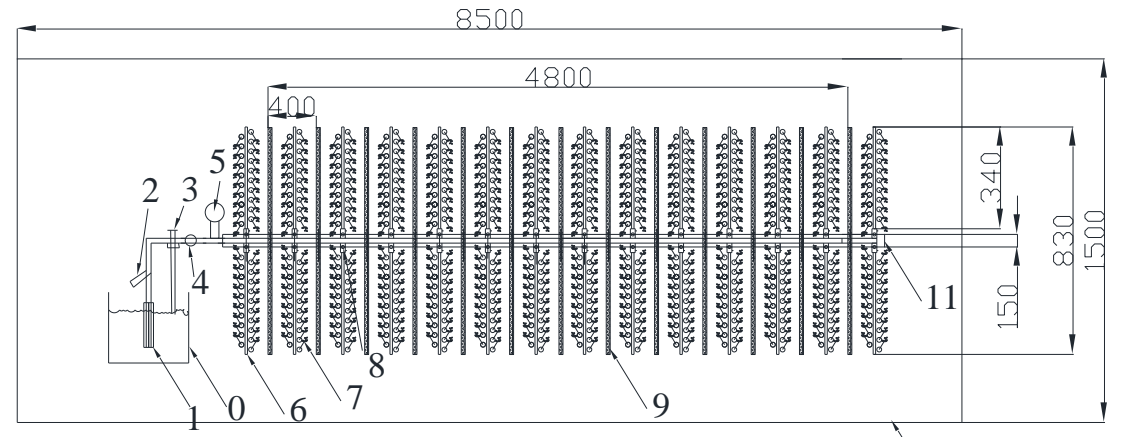

10

Figure 2. Schematic diagram of greenhouse layout $(\mathrm{cm})$. Note: 0 - water tank; 1 - the pump (WQD10-12-0.75S, PEOPLE PUMB, Crop., Shanghai, China); 2 - filter; 3 - backwater valve; 4 - electromagnetic flowmeter; 5 - pressure gauge; 6 - capillary; 7 - tomato; 8 - capillary valve; 9 - plastic screens; 10 - greenhouse boundaries; 11 - pathway

Table 1. Experimental factor and design

\begin{tabular}{c|c|c|c|c|c}
\hline No. & Treatment & Irrigation method & $\begin{array}{c}\text { Micropores group } \\
\text { spacing } \mathbf{~ c m}\end{array}$ & $\begin{array}{c}\text { Capillary arrangement } \\
\text { density }\end{array}$ & $\begin{array}{c}\text { Irrigation } \\
\text { amount mm }\end{array}$ \\
\hline 1 & L1C1 & & 30 & one pipe for one row & \\
2 & L1C2 & & 30 & one pipe for two rows & \\
3 & L1C3 & MSPF & 30 & one pipe for three rows & \\
4 & L2C1 & 50 & one pipe for one row & \\
5 & L2C2 & 50 & one pipe for two rows & 353.30 \\
6 & L2C3 & 50 & one pipe for three rows & \\
7 & CK1 & $\begin{array}{c}\text { Drip irrigation under } \\
\text { plastic film }\end{array}$ & 30 & one pipe for two rows & \\
8 & CK2 & $\begin{array}{c}\text { Micro-sprinkler } \\
\text { irrigation }\end{array}$ & 10 & one pipe for two rows & \\
\hline
\end{tabular}

\section{Experimental design}

Two factors were set up in this study: micropores group spacing L (Fig. 3) and capillary arrangement density $\mathrm{C}$ (Fig. 4). Of these, the micropores group spacing (L) used two levels: $30 \mathrm{~cm}$ (L1) and $50 \mathrm{~cm}$ (L2); the capillary arrangement density (C) used three levels: one pipe for one row (one capillary pipe irrigated one crop, C1), one pipe for two rows (one capillary pipe irrigated two rows of crops, C2), one pipe for three rows (one capillary pipe irrigated three rows of crops, C3). One pipe for two rows were used for 
both CK1 and CK2 control treatments. A total of eight treatments were implemented, each of which was repeated three times, for total of 24 test areas (Table 1).

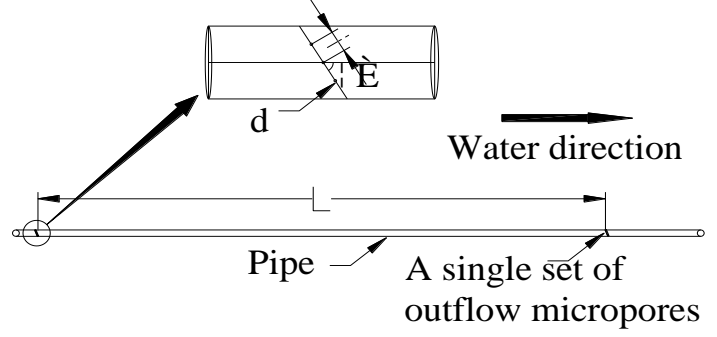

Figure 3. Schematic diagram of micropores group (inside) spacing structure parameters. Note: diameter of micropore is $d=0.7 \mathrm{~mm}$; The internal spacing of the micropores group spacing was $i=0.4 \mathrm{~cm}$; The Angle of micropores is $=68^{\circ}$; The micropores group spacing is $L$

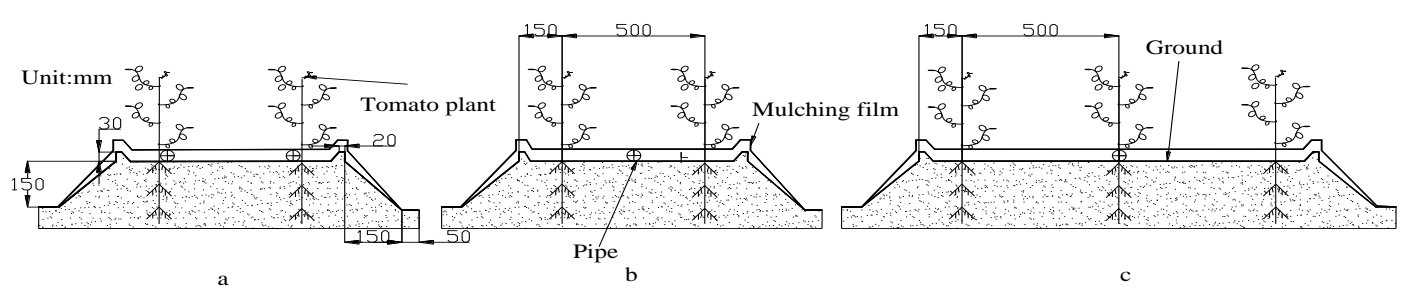

Figure 4. Schematic diagram of capillary arrangement density (a: one pipe for one row; $b$ : one pipe for two rows; $c$ : one pipe for three rows)

The irrigation amount was controlled on the basis of the cumulative evaporation from a 20-cm diameter standard pan ( $\mathrm{E}_{\mathrm{pan}}$, DY.AM3, Weifang Dayu Hydrology Technology Co., Ltd., Shandong, China) following Dinc et al. (2018) and Liu et al. (2013). The evaporation amount was measured at 08:00 am every $5 \mathrm{~d}$. The irrigation amount was evaluated after the measurement. The $W$ of irrigation quota was calculated according to Formula (Eq.1), and the irrigation times and amounts were recorded (Fig. 5).

$$
W=A \times E_{\text {pan }} \times k_{c p}
$$

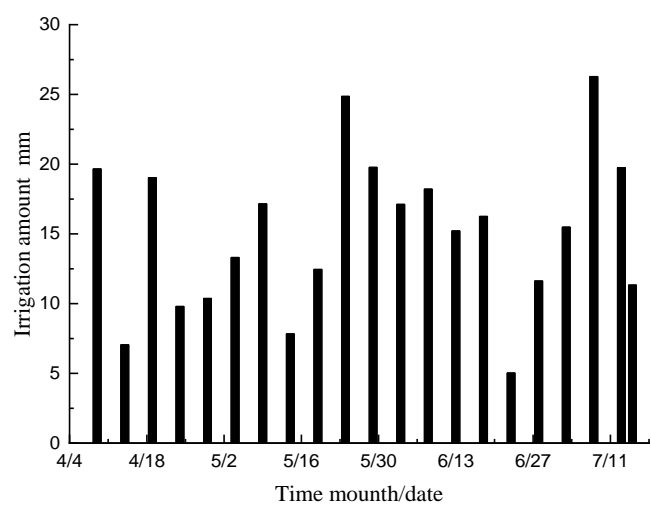

Figure 5. Irrigation records 
In the formula: $E_{\text {pan }}$ represents the evaporation within the interval of two irrigation, basing on the cumulative evaporation from a $20 \mathrm{~cm}$ diameter pan $(\mathrm{mm}) ; A$ represents the capillary control area $(\mathrm{mm})$, and $k_{c p}$ represents the crop- pan coefficient. In this paper, adopting adequate irrigation mode, the crop- pan coefficient of $k_{c p}$ is 1.0 (Zhu et al., 2020).

\section{Measurements and computational methods}

\section{Growth}

The growth-related indexes were measured at 26, 51, 73, and 110 days after planting, and three plants were randomly selected from each plot. Plant height $(\mathrm{PH})$ was measured with a ruler (Ma and Upadhyaya, 2016); the stem diameter (SD) was measured with electronic Vernier calipers at the base stem (Ma and Upadhyaya, 2016), and the leaf area index (LAI) was measured by AccuPARLP-80 canopy analyzer (Decagon Devices, Inc., Pullman, Wash. USA).

Three tomato plants were randomly selected in each plot, the stem of the plant was assumed as the center, and a hole was dug with a straight diameter of about $0.2 \mathrm{~m}$ and a depth of about $0.4 \mathrm{~m}$ to obtain the root system of the plant. Rhizosphere soil was carefully shaken off and the residual root system was slowly washed to remove the soil, using a weak water flow. Then, the root system and soil were placed on a 100-mesh steel screen during flushing to minimize root loss. After washing, the root system was dried in an oven at $105^{\circ} \mathrm{C}$ for $15 \mathrm{~min}$, followed by drying at $75^{\circ} \mathrm{C}$ to constant weight. Finally, the dry matter mass of the root system was obtained.

\section{Quality}

Fruit shape, flavor, and nutritional indexes are the main three factors of tomato quality. Three tomato fruits were randomly selected in each plot when the tomatoes were ripe at the first stage. Individual fruits were homogenized to determine the fruit flavor and nutritional indexes.

Shape indices: The weight of single fruit (SFW) was measured using precision $0.01 \mathrm{~g}$ electronic scale. Vertical diameters (VD) and transverse diameters (TD) of the fruit were measured using vernier calipers.

Flavor indices: The total soluble solids (TSS) was measured using a hand-held refractometer with automatic temperature compensation (PR-32 $\alpha$ Atago, Tokyo, Japan); the total soluble sugar (TSU) was measured using anthrone method (Decruyenaere et al., 2012). The soluble solid content (SSC) was measured using anthrone method (Liu et al., 2019). Titratable acids (TA) were determined by diluting an aliquot of the blended fruit and titrating against $0.1 \mathrm{~mol} / \mathrm{L} \mathrm{NaOH}$ using phenolpthalein as an indicator. Titratable acids (TA) content was determined by diluting an aliquot of the blended fruit and titrating against $0.1 \mathrm{~mol} / \mathrm{L} \mathrm{NaOH}$ by using phenolphthalein as an indicator. TAs were estimated by $\mathrm{mL}$ aliquot of blended fruit (Gould, 1992). Sugar/acid ratio (SAR) was determined by dividing the soluble sugar concentration by titratable acid.

Nutritional indices: the soluble protein (SP) content was measured using Coomassie Brilliant Blue assay (Liu et al., 2019). The vitamin C (VC ) was calculated by the classical titration method with 2,6-dichlorophenol indophenols sodium salt solutions (Liu et al., 2019). Lycopene (LY) was extracted with $2 \%$ dichloromethane and petroleum as solvents to enhance its solubility and the absorption at $502 \mathrm{~nm}$ was measured using ultraviolet spectrophotometer (Cefali et al., 2015). 


\section{Yield and water use efficiency}

During the maturation period, 4 tomatoes were randomly selected from each plot and the quality of mature tomatoes was measured using an electronic scale. After obtaining yield per plant, the yield per hectare was derived.

Time-domain reflectometry soil moisture sensor (TRIME-PICO-IPH, IMKO, Inc., Ettlingen, Germany) was used to measure the soil volume moisture content of $0-10,10$ $20,20-30,30-40,40-50,50-60,60-70$, and 70-80-cm soil layers. It was measured once before and after each growth period. Two monitoring points were selected in each district as shown in Figure 6 (monitoring point 1 was arranged at the outflow micropore; monitoring points 2 was arranged at distance $m$ between the two groups of micropore in the vertical flow direction, where $\mathrm{m}=25 \mathrm{~cm})$. Water consumption $\left(E T_{a}\right)$ and crop water use efficiency (WUE) were calculated using formula (Eq.2) and (Eq.3), respectively (Du et al., 2017).

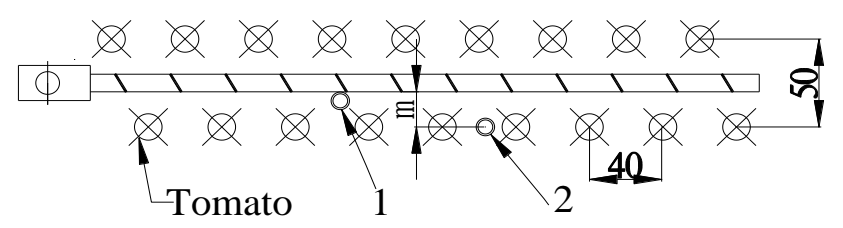

Figure 6. Schematic diagram of capillary and TRIME pipe arrangement (unit: cm)

$$
E T_{a}=I \pm 1000 \times H \times\left(\theta_{t 1}-\theta_{t 2}\right)
$$

In the formula, $E T_{a}$ represents crop water consumption during growth period (mm); $I$ represents the irrigation quota of crop growth period $(\mathrm{mm}) ; H$ represents the depth of the wetting layer with plan $(\mathrm{H}=0.8 \mathrm{~m}) ; \theta_{t 1}$ and $\theta_{t 2}$ represent $80-\mathrm{cm}$ average soil volumetric water content at times $t 1$ and $t 2\left(\mathrm{~cm}^{3} / \mathrm{cm}^{3}\right)$, respectively.

$$
W U E=Y / E T_{a}
$$

In the formula, $W U E$ indicates crop water use efficiency $\left(\mathrm{kg} / \mathrm{m}^{3}\right) ; Y$ indicates crop grain yield $\left(\mathrm{kg} / \mathrm{hm}^{2}\right)$.

\section{Standardization and homogenization of raw data}

In order to eliminate the influence of different evaluation indices dimensions, first standardize the data, and at the same time, in order to ensure that the evaluation indices has the same direction, it is also necessary to carry out the same chemotactic treatment of the data, reference to "Effect of planting row spacing and irrigation amount on comprehensive quality of short-season cultivation tomato in solar greenhouse in northwest china" (Wu et al., 2018), which is convenient for the selection of reference vectors when constructing the comprehensive benefit evaluation model by TOPSIS method.

\section{Data analysis}

Data was tested for normal distribution, which was followed by evaluation of the differences between groups, using SPSS22.0 (IBM Crop., Armonk, NY, USA). F test was 
used and the significant level was set to $P<0.05$. OriginPro2019 (Origin Lab Corporation, Northampton, MA, USA) was used to draw plots. Except for special annotations, the data are visualized by showing averages \pm standard deviations.

\section{Results}

\section{Effects of different treatments on plant height, stem diameter, and leaf area indexes on plant growth of tomato}

Table 2 shows the effects of different treatments on $\mathrm{PH}, \mathrm{SD}$, and LAI of tomato. With progressing tomato growth, $\mathrm{PH}$ and LAI increased first and then decreased, while SD increased. The PH, SD, and LAI of L1C2 were higher than those of CK1 and CK2 by $7.34 \%$ and $0.13 \%, 8.32 \%$ and $4.69 \%, 22.95 \%$ and $2.76 \%$, respectively. With decreasing capillary arrangement density, $\mathrm{PH}, \mathrm{SD}$, and LAI of tomato decreased, and no significant difference was found between $\mathrm{C} 1$ and $\mathrm{C} 2(P>0.05) . \mathrm{C} 1$ and $\mathrm{C} 2$ were significantly higher than $\mathrm{C} 3$ by about $10.64 \%$ and $7.15 \%, 8.35 \%$ and $7.10 \%, 24.97 \%$ and $17.14 \%(P<0.05)$, respectively. The $\mathrm{PH}, \mathrm{SD}$, and $\mathrm{LAI}$ of $30 \mathrm{~cm}$ tomato were $1.04,1.03$, and 1.14 times that of the $50 \mathrm{~cm}$ micropores group spacing.

Table 2. Experimental factor and design Effects of different treatments on PH, SD and LAI

\begin{tabular}{c|c|c|c|c|c}
\hline Indices & Treatment & $\begin{array}{c}\text { 26 days after } \\
\text { planting }\end{array}$ & $\begin{array}{c}\text { 51 days after } \\
\text { planting }\end{array}$ & $\begin{array}{c}\text { 73 days after } \\
\text { planting }\end{array}$ & $\begin{array}{c}\text { 110 days after } \\
\text { planting }\end{array}$ \\
\hline \multirow{6}{*}{$\mathrm{PH}$} & L1C1 & $41.96 \pm 3.62 \mathrm{a}$ & $105.12 \pm 12.5 \mathrm{a}$ & $137.2 \pm 7.03 \mathrm{a}$ & $137.13 \pm 9.01 \mathrm{a}$ \\
& L1C2 & $41.72 \pm 2.05 \mathrm{a}$ & $102.47 \pm 12.84 \mathrm{a}$ & $135.17 \pm 13.79 \mathrm{ab}$ & $135.47 \pm 14.85 \mathrm{a}$ \\
& L1C3 & $37.18 \pm 2.98 \mathrm{bc}$ & $95.54 \pm 25.77 \mathrm{ab}$ & $127.08 \pm 18.08 \mathrm{ab}$ & $128.53 \pm 14.58 \mathrm{ab}$ \\
& L2C1 & $40.54 \pm 2.24 \mathrm{abc}$ & $103.09 \pm 14.44 \mathrm{a}$ & $135.28 \pm 14.51 \mathrm{ab}$ & $135.88 \pm 12.12 \mathrm{ab}$ \\
& L2C2 & $38.39 \pm 4.38 \mathrm{abc}$ & $98.13 \pm 8.89 \mathrm{ab}$ & $128.62 \pm 8.47 \mathrm{ab}$ & $129.86 \pm 6.36 \mathrm{ab}$ \\
& L2C3 & $36.43 \pm 4.79 \mathrm{c}$ & $84.49 \pm 10.61 \mathrm{~b}$ & $123.79 \pm 13.8 \mathrm{~b}$ & $122.73 \pm 13.73 \mathrm{~b}$ \\
& CK1 & $37.74 \pm 6.66 \mathrm{abc}$ & $87.09 \pm 13.41 \mathrm{~b}$ & $130.88 \pm 4.8 \mathrm{ab}$ & $130.74 \pm 3.63 \mathrm{ab}$ \\
& CK2 & $41.42 \pm 3.94 \mathrm{ab}$ & $103.27 \pm 8.84 \mathrm{a}$ & $134.51 \pm 8.44 \mathrm{ab}$ & $135.08 \pm 5.94 \mathrm{a}$ \\
\hline \multirow{6}{*}{ SD } & L1C1 & $8.71 \pm 1.13 \mathrm{a}$ & $10.25 \pm 1.28 \mathrm{a}$ & $12.02 \pm 1.21 \mathrm{a}$ & $12.5 \pm 1.18 \mathrm{ab}$ \\
& L1C2 & $8.93 \pm 1.22 \mathrm{a}$ & $10.65 \pm 1.05 \mathrm{a}$ & $12.32 \pm 0.25 \mathrm{a}$ & $12.88 \pm 0.91 \mathrm{a}$ \\
& L1C3 & $8.29 \pm 1.67 \mathrm{a}$ & $9.9 \pm 1.75 \mathrm{a}$ & $11.78 \pm 1.03 \mathrm{a}$ & $11.54 \pm 1.4 \mathrm{~b}$ \\
& L2C1 & $8.84 \pm 1.74 \mathrm{a}$ & $10.5 \pm 1.14 \mathrm{a}$ & $12.46 \pm 0.75 \mathrm{a}$ & $12.31 \pm 0.89 \mathrm{ab}$ \\
& L2C2 & $8.69 \pm 1.19 \mathrm{a}$ & $9.82 \pm 1.11 \mathrm{a}$ & $11.66 \pm 0.55 \mathrm{a}$ & $11.64 \pm 0.59 \mathrm{~b}$ \\
& L2C3 & $8.16 \pm 1.84 \mathrm{a}$ & $9.41 \pm 1.47 \mathrm{a}$ & $11.49 \pm 0.99 \mathrm{a}$ & $10.28 \pm 0.93 \mathrm{~b}$ \\
& CK1 & $8.4 \pm 1.75 \mathrm{a}$ & $9.42 \pm 0.86 \mathrm{a}$ & $11.68 \pm 1.43 \mathrm{a}$ & $11.83 \pm 0.48 \mathrm{~b}$ \\
& CK2 & $8.48 \pm 1.58 \mathrm{a}$ & $10.12 \pm 0.85 \mathrm{a}$ & $11.89 \pm 0.87 \mathrm{a}$ & $12.29 \pm 0.81 \mathrm{ab}$ \\
\hline
\end{tabular}

Note: PH, Plant height; SD, Stem diameter; LAI, Leaf area indexes, the data are all average \pm standard deviation in the chart, different letters in the same column meant significant difference at 0.05 level, the same as blow 


\section{Effects of different treatments on tomato quality}

In terms of fruit shape indexes (Table 3), compared with CK1 and CK2, SFW, VD, and TD of L1C2 increased by $28.38 \%$ and $5.66 \%, 11.70 \%$ and $4.69 \%, 14.43 \%$ and $1.67 \%$, respectively. Under the same irrigation amount, with decreasing capillary arrangement density, the SFW, VD, and TD of tomato followed a decreasing trend, and decreased by about $34.10 \%, 16.38 \%$, and $9.98 \%$, respectively. The SFW, VD, and TD in the $30 \mathrm{~cm}$ micropores group spacing were 1.20,1.04, and 1.10 times higher than that of the $50 \mathrm{~cm}$ micropores group spacing.

In terms of fruit flavor indexes (Table 3), compared with CK1, the TSS, TSU, and SAR of L1C2 decreased by $0.32 \%, 3.30 \%$, and $0.31 \%$, respectively. Compared with CK2, the TSS, TSU, and SAR of L1C2 increased by $20.00 \%, 12.35 \%$, and $26.63 \%$, respectively. The spacing of micropores significantly affected the TSS of tomato $(P<0.05)$, and the capillary arrangement density significantly affected both TSS and SAR $(P<0.05)$. In the micropores group with $30 \mathrm{~cm}$ spacing, TSS, TSU, and SAR were 1.06, 1.04, and 1.02 times higher than that of $50 \mathrm{~cm}$ spacing. Under the same irrigation amount, TSS, TSU, and SAR increased by $15.38 \%, 10.30 \%$, and $23.75 \%$, respectively, with decreasing capillary arrangement density.

In terms of fruit nutritional indexes (Table 3), compared with $\mathrm{CK} 1, \mathrm{~L} 1 \mathrm{C} 2$ tomato flavor indices SP, VC, and LY decreased by $0.12 \%, 0.08 \%$, and $2.67 \%$, respectively; compared with CK2, these increased by $0.02 \%, 18.39 \%$, and $9.40 \%$, respectively. The micropores group spacing significantly affected the $\mathrm{VC}$ of tomato $(P<0.05)$, and the capillary arrangement density significantly affected the SP, VC, and LY $(P<0.05)$. In the $30 \mathrm{~cm}$ micropores group spacing, SP, VC, and LY were 1.05, 1.13, and 0.99 times as much as that of the $50 \mathrm{~cm}$ spacing. Under the same irrigation amount, the SP, VC, and LY increased by $8.72 \%, 16.07 \%$, and $13.28 \%$, respectively, with decreasing capillary arrangement density.

\section{Effects of different treatments on water consumption, yield, and water use efficiency of tomato}

Compared with CK1, the water consumption and yield of L1C2 was significantly higher than $8.46 \%, 19.39 \%(P<0.05)$, and there was no significant difference in the improvement of WUE $(10.03 \%, P>0.05$; Fig. 7). Compared with CK2, there was no significant difference in the increase of L1C2 yield ( $4.69 \%, P>0.05)$; however, the water consumption was significantly decreased by $8.01 \%(P<0.05)$ and WUE was significantly increased by $13.87 \%$ ( $P<0.05$ ). Compared with L1C1, L1C3, L2C1, L2C2, and $\mathrm{L} 2 \mathrm{C} 3$, the yield and WUE of L1C2 increased by $0.99 \%$ and $0.99 \%, 47.18 \%$ and $47.18 \%, 13.69 \%$ and $13.69 \%, 24.74 \%$ and $24.74 \%$, as well as $52.08 \%$ and $52.08 \%$, respectively. At the same time, the micropores group spacing and capillary arrangement density significantly affected yield and WUE $(P<0.05)$, and the interaction of both factors had significant effects on WUE $(P<0.05)$. With decreasing capillary arrangement density, the water consumption, yield, and WUE of tomato decreased. The yield and WUE of $\mathrm{C} 1$ and $\mathrm{C} 2$ were significantly higher than those of $\mathrm{C} 3$ by about $39.85 \%$ and $34.76 \%, 32.10 \%$ and $31.94 \%(P<0.05)$; however, there was no significant difference in yield and WUE between $\mathrm{C} 1$ and $\mathrm{C} 2(P>0.05)$. The water consumption, yield, and WUE of the $30 \mathrm{~cm}$ micropores group spacing were 1.01, 1.14, and 1.13 times higher than that of the $50 \mathrm{~cm}$ micropores group spacing. 
Table 3. Effects of different treatments on the quality of greenhouse tomato

\begin{tabular}{|c|c|c|c|c|c|c|c|c|c|}
\hline \multirow{2}{*}{ Treatment } & \multicolumn{3}{|c|}{ Shape indices } & \multicolumn{3}{|c|}{ Flavor indices } & \multicolumn{3}{|c|}{ Nutritional indices } \\
\hline & SFW g & VD mm & TD mm & TSS \% & TSU\% & SAR & SP mg/g & VC mg/g & LY \% \\
\hline $\mathrm{L} 1 \mathrm{C} 1$ & $138.56 \pm 21.99 a$ & $56.7 \pm 7.24 \mathrm{a}$ & $64.28 \pm 8.36 \mathrm{a}$ & $4.14 \pm 0.39 \mathrm{~d}$ & $6.97 \pm 1.34 \mathrm{a}$ & $6.62 \pm 0.96 b c$ & $5.19 \pm 0.67 \mathrm{ab}$ & $15.98 \pm 2.28 b c$ & $54.36 \pm 10.32 b$ \\
\hline $\mathrm{L} 1 \mathrm{C} 2$ & $139.42 \pm 25.75 \mathrm{a}$ & $57.86 \pm 4.17 \mathrm{a}$ & $66.28 \pm 5.06 \mathrm{a}$ & $5.17 \pm 0.66 \mathrm{a}$ & $7.75 \pm 1.6 \mathrm{a}$ & $8.2 \pm 1.61 \mathrm{ab}$ & $5.39 \pm 0.39 \mathrm{ab}$ & $19.19 \pm 2.44 \mathrm{a}$ & $62.48 \pm 8.15 \mathrm{ab}$ \\
\hline $\mathrm{L} 1 \mathrm{C} 3$ & $106.59 \pm 43.91 \mathrm{ab}$ & $52.09 \pm 3.88 \mathrm{ab}$ & $58.93 \pm 10.33 \mathrm{ab}$ & $4.92 \pm 0.47 \mathrm{ab}$ & $7.87 \pm 1.47 \mathrm{a}$ & $8.54 \pm 2.03 \mathrm{a}$ & $5.63 \pm 0.48 \mathrm{a}$ & $19.1 \pm 2.63 \mathrm{a}$ & $65.58 \pm 11.39 \mathrm{a}$ \\
\hline $\mathrm{L} 2 \mathrm{C} 1$ & $119.65 \pm 31.97 \mathrm{ab}$ & $58.88 \pm 7.19 \mathrm{a}$ & $59.28 \pm 5.14 \mathrm{ab}$ & $4.07 \pm 0.53 \mathrm{~d}$ & $6.84 \pm 1.32 \mathrm{a}$ & $6.34 \pm 2.15 c$ & $4.89 \pm 0.56 \mathrm{~b}$ & $14.63 \pm 1.46 \mathrm{c}$ & $58.75 \pm 10.13 \mathrm{ab}$ \\
\hline $\mathrm{L} 2 \mathrm{C} 2$ & $113.92 \pm 45.17 \mathrm{ab}$ & $53.21 \pm 7.72 \mathrm{ab}$ & $59.58 \pm 7.86 \mathrm{ab}$ & $4.57 \pm 0.13 b c$ & $7.39 \pm 1.25 \mathrm{a}$ & $8.19 \pm 1.71 \mathrm{ab}$ & $5.15 \pm 0.47 \mathrm{ab}$ & $16.22 \pm 1.55 \mathrm{bc}$ & $60.48 \pm 8.59 \mathrm{ab}$ \\
\hline $\mathrm{L} 2 \mathrm{C} 3$ & $85.96 \pm 55.67 \mathrm{~b}$ & $47.23 \pm 11.69 b$ & $53.52 \pm 11.13 \mathrm{ab}$ & $4.79 \pm 0.17 \mathrm{ab}$ & $7.53 \pm 1.06 \mathrm{a}$ & $8.45 \pm 1.2 \mathrm{a}$ & $5.42 \pm 0.51 \mathrm{ab}$ & $17.38 \pm 2.89 \mathrm{ab}$ & $64.85 \pm 9.05 \mathrm{a}$ \\
\hline CK1 & $108.6 \pm 49.35 \mathrm{ab}$ & $51.8 \pm 10.09 \mathrm{ab}$ & $57.92 \pm 11.04 \mathrm{~b}$ & $5.19 \pm 0.56 \mathrm{a}$ & $8.01 \pm 1.7 \mathrm{a}$ & $8.23 \pm 0.47 \mathrm{ab}$ & $5.39 \pm 0.51 \mathrm{aab}$ & $19.21 \pm 2.07 \mathrm{a}$ & $64.15 \pm 9.75 \mathrm{ab}$ \\
\hline $\mathrm{CK} 2$ & $131.95 \pm 33.22 \mathrm{a}$ & $55.26 \pm 6.05 \mathrm{a}$ & $65.19 \pm 7.21 \mathrm{a}$ & $4.31 \pm 0.38 \mathrm{~cd}$ & $6.9 \pm 1.7 \mathrm{a}$ & $6.48 \pm 1.8 \mathrm{c}$ & $5.39 \pm 0.25 \mathrm{ab}$ & $16.21 \pm 1.91 \mathrm{bc}$ & $57.11 \pm 7.26 \mathrm{ab}$ \\
\hline \multicolumn{10}{|l|}{ F-value } \\
\hline $\mathrm{L}$ & $1.4353 \mathrm{~ns}(2.9)$ & $6.368 *(11.7)$ & $0.618 \mathrm{~ns} \quad(1.3)$ & $5.112 *(9.6)$ & $0.569 \mathrm{~ns}(1.2)$ & $0.079 \mathrm{~ns}(0.2)$ & $3.022 \mathrm{~ns}(5.9)$ & $10.651 * *(18.2)$ & $0.044 \mathrm{~ns}(0.1)$ \\
\hline $\mathrm{C}$ & $5.722 * *(19.3)$ & $3.355^{*}(12.3)$ & $15.539 * * \quad(39.3)$ & $17.943 * *(42.8)$ & $1.787 \mathrm{~ns}(6.9)$ & $7.698 * *(24.3)$ & $3.833^{*}(13.8)$ & $8.513 * *(26.2)$ & $3.633^{*}(13.1)$ \\
\hline $\mathrm{L} \times \mathrm{C}$ & $1.301 \mathrm{~ns} \quad(5.1)$ & $0.950 \mathrm{~ns} \quad(0.2)$ & $11.741 * * \quad(32.9)$ & $2.044 \mathrm{~ns}(7.8)$ & $0.036 \mathrm{~ns}(0.2)$ & $0.031 \mathrm{~ns}(0.1)$ & $0.033 \mathrm{~ns}(0.1)$ & $0.628 \mathrm{~ns}(2.5)$ & $0.551 \mathrm{~ns}(2.2)$ \\
\hline
\end{tabular}

Notes: SFW, Single fruit weight; VH, Vertical height; TD, Transverse diameter; TSS, Total soluble solids; TSU, Total soluble sugar; SAR, Sugar / acid content ratio; SP, Soluble protein; Vc, Vitamin C; LY, Lycopene; the bracketed number is total variance relative contribution $\%$, *: $\mathrm{P}<0.05 ; * *: \mathrm{P}<0.01$; ns: $\mathrm{P}>0.05$ 

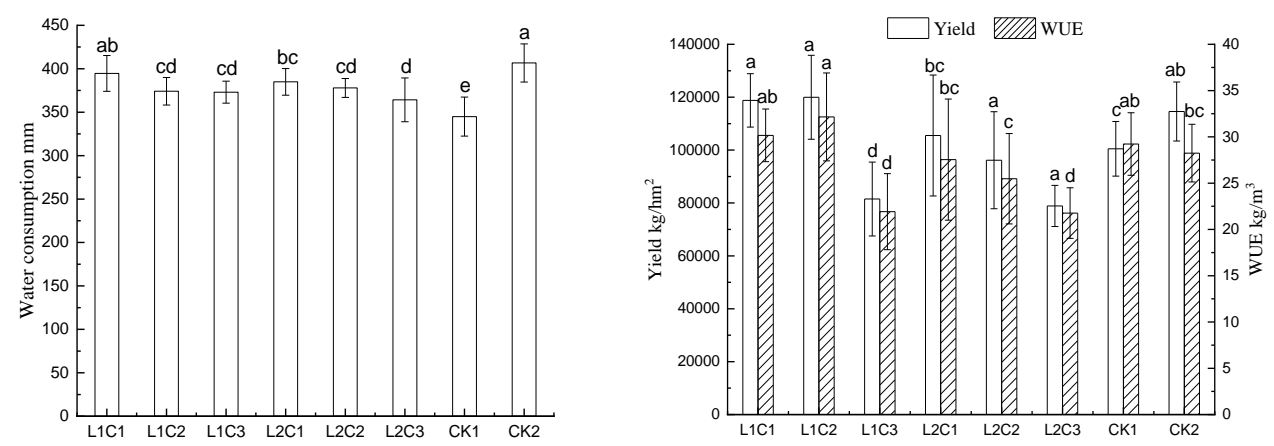

Figure 7. Effects of different treatments on tomato water consumption, yield and WUE. Note: the data are all average \pm standard deviation in the figure, different letters in the same column meant significant difference at 0.05 level, the same as blow

Optimal evaluation of comprehensive benefit of tomato quality, yield and water use efficiency based on the technique for order preference by similarity to an ideal solution method

The SFW, VD, TD, TSS, SP, TSU, VC, LY, SAR, yield, and WUE of tomato were selected as evaluation variables in Table 4. Firstly, these 11 indexes were weighted by Criteria Importance Though Intercrieria Correlation (CRITIC) method (Table 4). The calculation method is referred to the "effect of planting row spacing and irrigation amount on comprehensive quality of short-season cultivation tomato in solar greenhouse in northwest China" (Wu et al., 2018). The comprehensive benefit evaluation model is constructed by the TOPSIS method (Table 5), and the calculation method is referred to "optimizing irrigation frequency and amount to balance yield, fruit quality and WUE of greenhouse tomato" (Liu et al., 2019). The order of weight obtained by the CRITIC method was as follows: Yield $>\mathrm{SFW}>\mathrm{SAR}>\mathrm{WUE}>\mathrm{VD}>\mathrm{LY}>\mathrm{VC}>\mathrm{TSS}>\mathrm{TD}>$ TSU > SP, among which, the yield weight was highest (0.150). The evaluation results of the TOPSIS comprehensive benefit evaluation model showed that the comprehensive benefit of $\mathrm{L} 1 \mathrm{C} 2$ was best $(\mathrm{C} i=0.939)$, followed by $\mathrm{L} 1 \mathrm{C} 1$. The comprehensive benefit of drip irrigation under mulch ranked 4th, and micro-sprinkler irrigation ranked 3rd.

Table 4. Weighting values of each evaluation indices

\begin{tabular}{c|c|c|c|c|c|c|c|c|c|c|c}
\hline Indices & SFW & VD & TD & TSS & TSU & SAR & SP & VC & LY & Yield & WUE \\
\hline Weight & 0.144 & 0.081 & 0.067 & 0.074 & 0.054 & 0.124 & 0.040 & 0.076 & 0.070 & 0.150 & 0.120 \\
\hline
\end{tabular}

Table 5. The ranking of irrigation schedule calculated using TOPSIS for all the treatments

\begin{tabular}{c|c|c|c|c}
\hline Treatment & $\mathbf{D}^{+}$ & $\mathbf{D}^{-}$ & $\mathbf{C}_{\boldsymbol{i}}$ & Ranking \\
\hline L1C1 & 0.015 & 0.034 & 0.696 & 2 \\
L1C2 & 0.003 & 0.039 & 0.939 & 1 \\
L1C3 & 0.029 & 0.019 & 0.388 & 7 \\
L2C1 & 0.021 & 0.023 & 0.518 & 5 \\
L2C2 & 0.021 & 0.020 & 0.490 & 6 \\
L2C3 & 0.036 & 0.014 & 0.282 & 8 \\
CK1 & 0.018 & 0.024 & 0.575 & 4 \\
CK2 & 0.016 & 0.030 & 0.647 & 3 \\
\hline
\end{tabular}




\section{Discussion}

\section{Effects of irrigation methods on quality and yield of greenhouse tomato}

The yield and WUE of tomato plants under MSPF were $19.39 \%$ and $10.03 \%$ higher compared with drip irrigation under plastic film (Fig. 7). This may be because the flow rate of MSPF was about 45 times higher than that of the single group with drip irrigation under plastic film and identical working pressure. Under identical irrigation amount, the flow rate of the single group of MSPF exceeded that of drip irrigation with smaller orifice flow, and the irrigation time was shorter, so that the ratio of soil water horizontal to vertical migration distance increased. The larger surface wetting area increases the wetting volume and irrigation uniformity per unit area of the tillage layer, and decreases the deep transport of soil water (Topp, 1969; Zotarelli et al., 2009; Elmaloglou and Diamantopoulos, 2010; Selim et al., 2013). The average soil volume moisture content of the $0-40 \mathrm{~cm}$ soil layer under MSPF was $9.34 \%$ higher than that of drip irrigation under plastic film (Fig. 8) and root dry matter accumulation (Fig. 9). This provided a strong guarantee for the stable yield of greenhouse tomato (Ould et al., 2001), resulting in higher yield of tomato under MSPF. However, because of the large surface wetting area of MSPF and the vigorous growth of tomato plants, soil water evaporation was further intensified. Compared with drip irrigation under plastic film, the water consumption of tomato under MSPF increased by $8.46 \%$ (Fig. 7). The yield increase of MSPF (19.39\%) was about 2.29 times that of its water consumption (8.46\%); therefore, the WUE of crops under MSPF was higher than that of drip irrigation under plastic film. This study found that TSS, TSU, SAR, SP, VC, and LY of MSPF decreased by $0.32 \%, 3.30 \%, 0.31 \%, 0.12 \%, 0.08 \%$, and $2.67 \%$ compared with drip irrigation under plastic film. This may be due to the higher moisture content of tomato fruits under MSPF and excessive water dilution of fruit flavor and nutrition index content per unit mass. This is consistent with previous studies, which showed that with increasing irrigation water, the soil volume and water content increased, which reduce the tomato fruit flavor and nutritional content (Topp, 1969; Meek et al., 1992; Li et al., 2020).

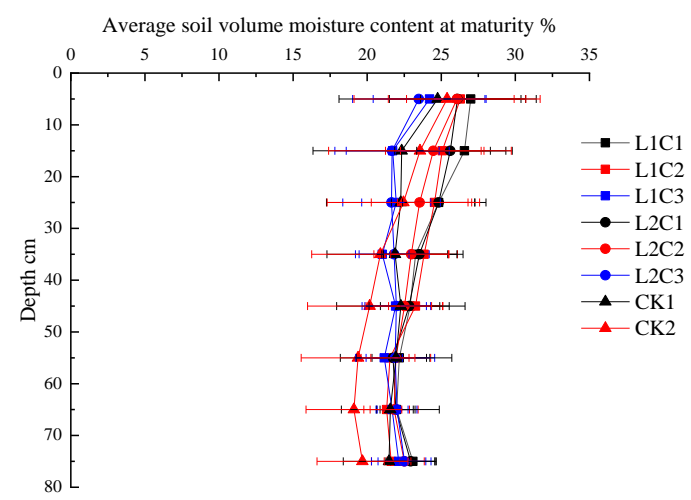

Figure 8. Average soil volume moisture content in different treatments at mature stage (70 days after transplant). Note: the data are all average \pm standard deviation in the figure

Compared with micro-sprinkler irrigation, the yield of tomato under MSPF increased by $4.69 \%$, because the micro-sprinkling irrigation water flows through the capillary pipe and is sprayed out through the micropore water flow on the capillary pipe wall. The spray height reached more than $1 \mathrm{~m}$ under normal working pressure. The spray water flow could 
easily be atomized and increase air humidity, thus resulting in tomato canopy humidity as high as $70 \%$, which is 1.56 times higher than that of MSPF (Fig. 10). Previous studies have shown that high-humidity environments can easily cause leaf moisture condensation, leaf cell rupture, decreased leaf photosynthesis, limited dry matter accumulation, and delayed fruit morphological development (Mortensen, 1992; Panchal et al., 2016). It is also possible that under the same amount of irrigation, part of the water is used to increase air humidity, which decreases soil water infiltration. The average volumetric moisture content of the $0-40 \mathrm{~cm}$ soil during the mature period was $7.48 \%$ lower than that of MSPF (Fig. 8). The lower soil volumetric moisture content decreased the increase of tomato yield. This study found that the WUE of tomato under MSPF was significantly higher (by $13.87 \%$ ) than that of micro-sprinkler irrigation. This may be because the yield of microsprinkler irrigation was lower than that of MSPF, and the water consumption of tomato under MSPF was significantly lower than that of micro-sprinkler irrigation (by $8.01 \%$; Fig. 7). This study also showed that the related indexes of tomato flavor and nutrition in micro-sprinkler irrigation were lower than those of MSPF. This may be due to the atomization of water droplets in micro-sprinkler irrigation, which increases air humidity and decreases the temperature difference between day and night in the greenhouse; these effects are not conducive to the accumulation of tomato flavor and nutritional indexes (Max et al., 2009; Luo et al., 2016; Sun et al., 2016).

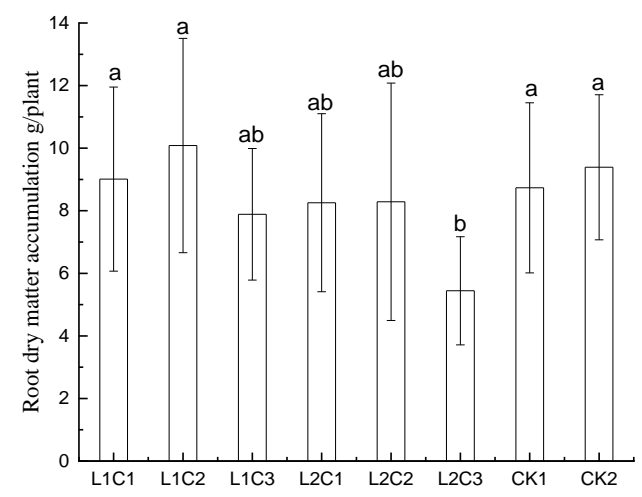

Figure 9. Effects of MSPF on dry matter accumulation of tomato root during mature stage. Note: the data are all average \pm standard deviation in the figure, different letters in the same column meant significant difference at 0.05 level, the same as blow

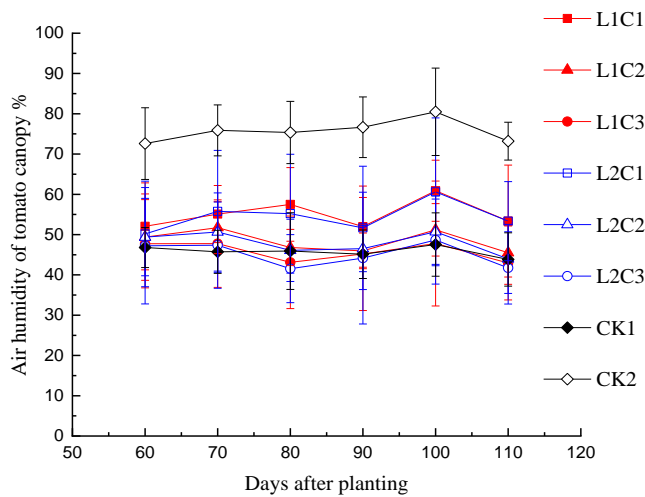

Figure 10. Effects of different treatments on air humidity in tomato canopy. Note: the data are all average \pm standard deviation in the figure 


\section{Effects of micropores group spacing on quality and yield of greenhouse tomato}

This study found that the PH, SD, LAI, and yield of tomato plants with the $30 \mathrm{~cm}$ micropores group spacing were better than that of those with $50 \mathrm{~cm}$ (Table 2). Maybe, the influence of the change of micropores group spacing with MSPF on the soil wetting body is similar to that of dripper spacing with drip irrigation under plastic film, and a phenomenon of intersection of wetting peaks between two groups of adjacent micropores on the capillary pipe was identified. The difference is that under the same working pressure and amount of irrigation, the single group flow of MSPF is higher than that of drip irrigation. Moreover, a larger flow rate easily increases the ratio of horizontal to vertical migration distance of soil water wetting peak. Shortening the confluence time of adjacent wetting peaks is beneficial to the overall deep transport of soil water between the two groups of micropores in the capillary, and improves the soil volume moisture content and irrigation uniformity in the tillage layer per unit area (Ould et al., 2001; Del et al., 2020). Diameter measurement showed that the $30 \mathrm{~cm}$ micropores group achieved better tomato maturity than that of the $50 \mathrm{~cm}$ micropore group, the average soil volume moisture content of the $0-40 \mathrm{~cm}$ soil layer increased by $1.60 \%$ (Fig. 8), and the higher soil volume moisture content of the tillage layer provided a strong guarantee for tomato growth (Abdelhafeez et al., 1975; Silveira et al., 2020). This is consistent with the conclusion that PH, SD, LAI, and yield of pomegranate, as studied by Meshram et al. (2019), were higher than that of $50 \mathrm{~cm}$.

The present study showed that micropores group spacing had a significant effect on tomato yield. Wang et al. (2005), did not find a significant difference in cucumber yield between 50 and $30 \mathrm{~cm}$ drippers spacing when drip irrigation was used, which may be due to the different amounts of irrigation in their experiment. In this study, the irrigation amount was controlled by evaporation pan, and the cumulative amount of irrigation was $353 \mathrm{~mm}$, while Wang controlled the lower limit of soil irrigation and irrigated $385 \mathrm{~mm}$ during the growth period. Enciso et al. (2007) found no significant difference in onion yield under different dripper spacings, and the conclusion that the micropores group spacing had a significant effect on tomato yield, as found in this study, is also inconsistent. Because the maximum spacing of dripper set by Enciso was $30 \mathrm{~cm}$ (which was much smaller than $50 \mathrm{~cm}$ in this study), the soil water distribution was uniform, and could not easily cause yield differences because of drought stress on crops (Ould et al., 2001; Jiménez et al., 2010). Furthermore, the WUE of micropores group spacing at $30 \mathrm{~cm}$ was 1.13 times higher than that of $50 \mathrm{~cm}$ (Fig. 7). It is possible that the soil volume of the tillage layer with a micropores group spacing of $30 \mathrm{~cm}$ is moist and uniform, and there is no obvious high water and bottom water area, which can accurately and in time meet the water demand of plants ( $\mathrm{Li}$ et al., 2018b), resulting in a significant increase in tomato yield. At the same time, the water consumption of the $30 \mathrm{~cm}$ micropores group spacing did not significantly increase (Fig. 7), and finally showed a significant improvement in WUE (Wang et al., 2005; Li et al., 2019c). Elmaloglou and Diamantopoulos (2010) suggested that decreased dripper spacing can shorten irrigation duration and improve irrigation efficiency, which is consistent with the conclusion that reducing the micropores group spacing to $30 \mathrm{~cm}$ can improve WUE.

Previous studies found that too high or too low soil moisture can decrease the contents of soluble solids, VC, and lycopene (Wu et al., 2018). This study showed that the flavor and nutrition of tomato with the $30 \mathrm{~cm}$ micropores group spacing were better than that of $50 \mathrm{~cm}$, indicating that the soil moisture distribution at $30 \mathrm{~cm}$ micropores group spacing was more suitable spacing for greenhouse tomato under MSPF. This study also found that 
micropores group spacing had a significant effect on tomato TSS, which was inconsistent with the conclusion of Enciso et al. (2007) who reported that dripper spacing had no significant effect on onion solids. The reason for this difference is mainly because all water required by tomato plants originated from irrigation water, while Enciso's onion water requirements were also met by rainfall, which could provide similar irrigation water and optimal soil moisture conditions in all treatments.

\section{Effects of capillary arrangement density on tomato quality and yield in greenhouse}

The study of the capillary arrangement density of tomato in the greenhouse showed that the PH, SD, LAI, yield, and water consumption of tomato plants decreased with decreasing capillary arrangement density. Because the same single group flow rate, micropores group spacing, and irrigation amount were used, the higher the capillary arrangement density, the higher the amount of flow per unit area. This makes it easy to increase the surface wetting area, which is conducive to the overall decreasing movement of surface soil moisture and decreases the deep migration of soil moisture. The average soil volume moisture content of one tube and two rows of tillage layer $(0-40 \mathrm{~cm})$ was significantly higher than that of one tube and three rows (Fig. 8). The higher soil volume moisture content in the higher tillage layer provides a strong guarantee for the growth and stable yield of tomato (Tracy et al., 2013).

With the decrease of capillary arrangement density, a lower surface wetting rate can easily reduce soil ineffective water evapotranspiration, and the lower LAI decreases leaf transpiration, resulting in decreased tomato water consumption. Wang et al. (2018a) found that the yield of tomato under greenhouse drip irrigation increased first and then decreased with decreasing capillary arrangement density. This was inconsistent with the decreasing trend the tomato yield showed in this study, which was mainly because of the different of soil types and irrigators used, and possibly also because of differences of capillary arrangement density used for drip irrigation. In this study, the arrangement of one tube and two rows was the maximum spacing of Wang's drip irrigation. With regard to the differences of tomato yield between three tubes for four rows and one tube and two rows with MSPF, further experiments are needed. The bermudagrass yield of Cantrell et al. (2009), the spring wheat yield of Lv et al. (2019), and the maize yield of Bozkurt et al. (2006) for drip irrigation decreased with decreasing capillary arrangement density. This conclusion is consistent with the conclusion of tomato yield with MSPF in this study.

Furthermore, TSS, TSU, SP, VC, and LY increased with decreasing capillary arrangement density (Table 3), which may be because under the same irrigation amount, the smaller the capillary arrangement density was, the longer the irrigation duration was. This aggravated the deep soil water transport and decreased the soil volume moisture content per unit area, thus resulting in a decrease of tomato fruit moisture content and increases of TSS, TSU, SP, VC, and LY concentration per unit weight tomato fruit (Patanè and Cosentino, 2010; Wang et al., 2018a,b). Wang et al. (2018a) found that the SAR of muskmelon in northwest China increased with decreasing capillary arrangement density under drip irrigation, which was consistent with the conclusion of SAR of tomato fruit in this study. This indicates that the effect of capillary arrangement density of microsprinkler irrigation on tomato taste was consistent with that of drip irrigation in this area. 


\section{Conclusions}

Under the same amount of irrigation, the spring and autumn tomato growth, fruit morphology, yield, and WUE were better with MSPF than with drip irrigation and microsprinkler irrigation. Improvements were about $7.34 \%$ and $0.13 \%, 8.32 \%$ and $4.69 \%$, $22.95 \%$ and $2.76 \%, 28.38 \%$ and $5.66 \%, 11.70 \%$ and $4.69 \%$, as well as $14.43 \%$ and $1.67 \%$, respectively. Compared with drip irrigation under plastic film, no significant decreases in fruit flavor and nutrition were found. TSS and VC were significantly higher than that of micro-sprinkler irrigation by about $20.00 \%$ and $19.39 \%$, indicating that MSPF was suitable for greenhouse tomato irrigation. With decreasing capillary arrangement density, tomato growth, fruit shape, yield, and WUE decreased, while tomato fruit flavor and nutrition increased. Compared with $50 \mathrm{~cm}$ micropores group spacing, $30 \mathrm{~cm}$ was beneficial for tomato growth, fruit quality, yield, and WUE. The comprehensive benefit evaluation model of tomato quality, yield, and WUE by the TOPSIS method and the comprehensive evaluation results of yield and WUE identified the L1C2 treatment as better. With the goal of improving WUE and low-cost investment without significantly reducing yield, it is recommended to use a combination of one pipe for two rows with a micropores group spacing of $30 \mathrm{~cm}$ in arid and semi-arid sandy loam soils. This study provides a theoretical basis and data support for the large-scale promotion of MSPF. While the presented results describe the optimum irrigation if the row spacing is $50 \mathrm{~cm}$, but it remains an open question that the further experiments are needed to investigate other row spacings.

Acknowledgments. This work is supported jointly by Natural Science Foundation of China (No. 41807041) and (No. 51579205), Natural Science Foundation of Guangdong Province (No. 2018A0303130149), Shaanxi Provincial Water Conservancy Science and Technology Project (2015slkj-07), Henan Water Conservancy Science and Technology Project (GG201602), Science and Technology Program of Xi'an (20193052YF040NS040), Science and Technology Program of Guangzhou (No.20181002SF0530), Fundamental Research Funds for the Central Universities (GK201903115), and the Program of Introducing Talents of Discipline to Universities (B16011). We are grateful for the helpful comments of the anonymous reviewers.

\section{REFERENCES}

[1] Abdelhafeez, A. T., Harssema, H., Verkerk, K. (1975): Effects of air temperature, soil temperature and soil moisture on growth and development of tomato itself and grafted on its own and egg-plant rootstock. - Scientia Horticulturae 3: 65-73.

[2] Baram, S., Dabach, S., Jerszurki, D., Stockert, C. M., Smart, D. R. (2018): Upscaling point measurements of $\mathrm{N} 2 \mathrm{O}$ emissions into the orchard scale under drip and microsprinkler irrigation. - Agriculture, Ecosystems \& Environment 265: 103-111.

[3] Bozkurt, Y., Yazar, A., Gençel, B., Sezen, M. S. (2006): Optimum lateral spacing for dripirrigated corn in the Mediterranean Region of Turkey. - Agricultural Water Management 85: 113-120.

[4] Camara, J., Logah, V., Osekre, E. A., Kwoseh, C. (2017): Leaf nutrients content of tomato and incidence of insect pests and diseases following two foliar applications. - Journal of Plant Nutrition 26: 159-167.

[5] Cantrell, K. B., Stone, K. C., Hunt, P. G., Ro, K. S., Vanotti, M. B., Burns, J. C. (2009): Bioenergy from Coastal bermudagrass receiving subsurface drip irrigation with advancetreated swine wastewater. - Bioresource Technology 100: 3285-3292. 
[6] Cefali, L. C., Cazedey, E. C. L., Souza-Moreira, T. M., Correa, M. A., Salgado, H. R. N., Isaac, V. L. B. (2015): Antioxidant Activity and Validation of Quantification Method for Lycopene Extracted from Tomato. - Journal of AOAC International 98: 1340-1345.

[7] Chen, R., Cheng, W., Cui, J., Liao, J., Fan, H., Zheng, Z., Ma, F. (2015): Lateral spacing in drip-irrigated wheat: The effects on soil moisture, yield, and water use efficiency. - Field Crops Research 179: 52-62.

[8] Decruyenaere, V., Clément, C., Agneessens, R., Losseau, C., Stilmant, D. (2012): Development of near-infrared spectroscopy calibrations to quantify starch and soluble sugar content in the roots of Rumex obtusifolius. - Weed Research 52: 1-5.

[9] Del Vigo, Á., Zubelzu, S., Juana, L. (2020): Numerical routine for soil water dynamics from trickle irrigation. - Applied Mathematical Modelling 83: 371-385.

[10] Dinc, N., Aydinsakir, K., Isik, M., Bastug, R., Ari, N., Sahin, A., Buyuktas, D. (2018): Assessment of different irrigation strategies on yield and quality characteristics of drip irrigated pomegranate under mediterranean conditions. - Irrigation Science 36: 87-96.

[11] Du, T., Kang, S., Zhang, X., Zhang, J. (2014): China's food security is threatened by the unsustainable use of water resources in North and Northwest China. - Food and Energy Security 3: 7-18.

[12] Du, Y., Cao, H., Liu, S., Gu, X., Cao, Y. (2017): Response of yield, quality, water and nitrogen use efficiency of tomato to different levels of water and nitrogen under drip irrigation in Northwestern China. - Journal of Integrative Agriculture 16: 1153-1161.

[13] Elmaloglou, S., Diamantopoulos, E. (2010): Soil water dynamics under surface trickle irrigation as affected by soil hydraulic properties, discharge rate, dripper spacing and irrigation duration. - Irrigation and Drainage 59: 254-263.

[14] Enciso, J., Jifon, J., Wiedenfeld, B. (2007): Subsurface drip irrigation of onions: Effects of drip tape emitter spacing on yield and quality. - Agricultural Water Management 92: 126130.

[15] Er, M. K., Gökçe, A. (2004): Effects of selected pesticides used against glasshouse tomato pests on colony growth and conidial germination of Paecilomyces fumosoroseus. Biological Control 31: 398-404.

[16] Feng, J., Li, Y., Wang, W., Xue, S. (2018): Effect of optimization forms of flow path on emitter hydraulic and anti-clogging performance in drip irrigation system. - Irrigation Science 36: 37-47.

[17] Fletcher, E., Morgan, K. T., Qureshi, J. A., Leiva, J. A., Nkedi-Kizza, P. (2018): Imidacloprid soil movement under micro-sprinkler irrigation and soil-drench applications to control Asian citrus psyllid (ACP) and citrus leafminer (CLM). - Plos One 13: 1-16.

[18] Gómez-Rodríguez, O., Zavaleta-Mejía, E., González-Hernández, V. A., Livera-Muñoz, M., Cárdenas-Soriano, E. (2003): Allelopathy and microclimatic modification of intercropping with marigold on tomato early blight disease development. - Field Crops Research 83: 2734.

[19] Gould, W. (1992): Tomato production, processing, and technology (3rd edition). - CTI Publications. Baltimore, USA.

[20] Jiménez, M., De Juan, J. A., Tarjuelo, J. M., Ortega, J. F. (2010): Effect of irrigation uniformity on evapotranspiration and onion yield. - The Journal of Agricultural Science 148: 139-157.

[21] Li, J., Xu, X., Lin, G., Wang, Y., Liu, Y., Zhang, M., Zhou, J., Wang, Z., Zhang, Y. (2018a): Micro-irrigation improves grain yield and resource use efficiency by co-locating the roots and $\mathrm{N}$-fertilizer distribution of winter wheat in the North China Plain. - Science of The Total Environment 643: 367-377.

[22] Li, X., Jin, M., Zhou, N., Jiang, S., Hu, Y. (2018b): Inter-dripper variation of soil water and salt in a mulched drip irrigated cotton field: Advantages of 3-D modelling. - Soil and Tillage Research 184: 186-194.

[23] Li, J., Wang, Y., Zhang, M., Liu, Y., Xu, X., Lin, G., Wang, Z., Yang, Y., Zhang, Y. (2019a): Optimized micro-sprinkling irrigation scheduling improves grain yield by 
increasing the uptake and utilization of water and nitrogen during grain filling in winter wheat. - Agricultural Water Management 211: 59-69.

[24] Li, J., Zhang, Z., Liu, Y., Yao, C., Song, W., Xu, X., Zhang, M., Zhou, X., Gao, Y., Wang, Z., Sun, Z., Zhang, Y. (2019b): Effects of micro-sprinkling with different irrigation amount on grain yield and water use efficiency of winter wheat in the North China Plain. Agricultural Water Management 224: 5736-5742.

[25] Li, Y., Niu, W., Cao, X., Wang, J., Zhang, M., Duan, X., Zhang, Z. (2019c): Effect of soil aeration on root morphology and photosynthetic characteristics of potted tomato plants (Solanum lycopersicum) at different $\mathrm{NaCl}$ salinity levels. - BMC Plant Biology 19: 25-36.

[26] Li, Y., Niu, W., Zhang, M., Wang, J., Zhang, Z. (2020): Artificial soil aeration increases soil bacterial diversity and tomato root performance under greenhouse conditions. - Land Degradation \& Development 48: 1-10.

[27] Liu, H., Yang, H., Zheng, J., Jia, D., Wang, J., Li, Y., Huang, G. (2012): Irrigation scheduling strategies based on soil matric potential on yield and fruit quality of mulcheddrip irrigated chili pepper in Northwest China. - Agricultural Water Management 115: 232 241.

[28] Liu, H., Duan, A., Li, F., Sun, J., Wang, Y., Sun, C. (2013): Drip Irrigation Scheduling for Tomato Grown in Solar Greenhouse Based on Pan Evaporation in North China Plain. Journal of Integrative Agriculture 12: 520-531.

[29] Liu, H., Li, H., Ning, H., Zhang, X., Li, S., Pang, J., Wang, G., Sun, J. (2019): Optimizing irrigation frequency and amount to balance yield, fruit quality and water use efficiency of greenhouse tomato. - Agricultural Water Management 226: 105-114.

[30] Luo, H. H., Zhang, Y. L., Zhang, W. F. (2016): Effects of water stress and rewatering on photosynthesis, root activity, and yield of cotton with drip irrigation under mulch. Photosynthetica 54: 65-73.

[31] Luo, H., Li, F. (2018): Tomato yield, quality and water use efficiency under different drip fertigation strategies. - Scientia Horticulturae 235: 181-188.

[32] Lv, Z., Diao, M., Li, W., Cai, J., Zhou, Q., Wang, X., Dai, T., Cao, W., Jiang, D. (2019): Impacts of lateral spacing on the spatial variations in water use and grain yield of spring wheat plants within different rows in the drip irrigation system. - Agricultural Water Management 212: 252-261.

[33] Ma, L., Upadhyaya, M. K. (2016): Effects of red/far-red light ratio on common lamb'squarters, redroot pigweed, and tomato plants. - Canadian Journal of Plant Science 97: 494500 .

[34] Malherbe, S., Marais, D. (2015): Economics, Yield and Ecology: A Case Study from the South African Tomato Industry. - Outlook on Agriculture 44: 37-47.

[35] Man, J., Wang, D., White, P. J., Yu, Z. (2014): The length of micro-sprinkling hoses delivering supplemental irrigation affects photosynthesis and dry matter production of winter wheat. - Field Crops Research 168: 65-74.

[36] Man, J., Yu, J., White, P. J., Gu, S., Zhang, Y., Guo, Q., Shi, Y., Wang, D. (2014): Effects of supplemental irrigation with micro-sprinkling hoses on water distribution in soil and grain yield of winter wheat. - Field Crops Research 161: 26-37.

[37] Man, J., Wang, D., White, P. J. (2017): Photosynthesis and Drymass Production of Winter Wheat in Response to Micro-Sprinkling Irrigation. - Agronomy Journal 109: 549-561.

[38] Massatbayev, K., Izbassov, N., Nurabaev, D., Musabekov, K., Shomantayev, A., Massatbayev, M. (2016): Technology and Regime of Sugar Beet Drip Irrigation with Plastic Mulching Under the Conditions of the Jambyl Region. - Irrigation and Drainage 65: 620-630.

[39] Max, J. F. J., Horst, W. J., Mutwiwa, U. N., Tantau, H. (2009): Effects of greenhouse cooling method on growth, fruit yield and quality of tomato (Solanum lycopersicum L.) in a tropical climate. - Scientia Horticulturae 122: 179-186. 
[40] Meek, B. D., Rechel, E. R., Carter, L. M., DeTar, W. R., Urie, A. L. (1992): Infiltration Rate of a Sandy Loam Soil: Effects of Traffic, Tillage, and Plant Roots. - Soil Science Society of America Journal 56: 908-913.

[41] Meshram, D. T., Gorantiwar, S. D., Singh, N. V., Babu, K. D. (2019): Response of microirrigation systems on growth, yield and WUE of Pomegranate (Punica granatum L.) in semi-arid regions of India. - Scientia Horticulturae 246: 686-692.

[42] Michelakis, N., Vougioucalou, E., Clapaki, G. (1993): Water use, wetted soil volume, root distribution and yield of avocado under drip irrigation. - Agricultural Water Management 24: 119-131.

[43] Mortensen, L. M. (1992): Effects of ozone concentration on growth of tomato at various light, air humidity and carbon dioxide levels. - Scientia Horticulturae 49: 17-24.

[44] Ould Mohamed El-Hafedh, A. V., Daghari, H., Maalej, M. (2001): Analysis of several discharge rate-spacing-duration combinations in drip irrigation system. - Agricultural Water Management 52: 33-52.

[45] Panchal, S., Chitrakar, R., Thompson, B. K., Obulareddy, N., Roy, D., Hambright, W. S., Melotto, M. (2016): Regulation of Stomatal Defense by Air Relative Humidity. - Plant Physiology 172: 2021-2032.

[46] Patanè, C., Cosentino, S. L. (2010): Effects of soil water deficit on yield and quality of processing tomato under a Mediterranean climate. - Agricultural Water Management 97: 131-138.

[47] Selim, T., Bouksila, F., Berndtsson, R., Persson, M. (2013): Soil Water and Salinity Distribution under Different Treatments of Drip Irrigation. - Soil Science Society of America Journal 77: 1144-1156.

[48] Silveira, L. K., Pavão, G. C., Dos Santos Dias, C. T., Quaggio, J. A., de Matos Pires, R. C. (2020): Deficit irrigation effect on fruit yield, quality and water use efficiency: A long-term study on Pêra-IAC sweet orange. - Agricultural Water Management 231: 106019.

[49] Sui, J., Wang, J., Gong, S., Xu, D., Zhang, Y., Qin, Q. (2018): Assessment of maize yieldincreasing potential and optimum $\mathrm{N}$ level under mulched drip irrigation in the Northeast of China. - Field Crops Research 215: 132-139.

[50] Sun, W. H., Wu, Y. Y., Wen, X. Y., Xiong, S. J., He, H. G., Wang, Y., Lu, G. Q. (2016): Different mechanisms of photosynthetic response to drought stress in tomato and violet orychophragmus. - Photosynthetica 54: 226-233.

[51] Topp, G. C. (1969): Soil-Water Hysteresis Measured in a Sandy Loam and Compared with the Hysteretic Domain Model. - Soil Science Society of America Journal 33: 645-651.

[52] Tracy, S. R., Black, C. R., Roberts, J. A., Mooney, S. J. (2013): Exploring the interacting effect of soil texture and bulk density on root system development in tomato (Solanum lycopersicum L.). - Environmental and Experimental Botany 91: 38-47.

[53] Tsitsimpelis, I., Wolfenden, I., Taylor, C. J. (2016): Development of a grow-cell test facility for research into sustainable controlled-environment agriculture. - Biosystems Engineering 150: 40-53.

[54] Wang, S., Li, G. Y., Meng, G. Q., Jia, Y., Wang, Z., Qiu, J., Duan, S. (2005): Effects of dripper discharge and spacing on growth of cucumber in Chinese solar greenhouse under drip irrigation. - Transactions of the Chinese Society of Agricultural Engineering 21: 167170.

[55] Wang, J., Niu, W., Dyck, M., Zhang, M., Li, Y. (2018a): Drip irrigation with film covering improves soil enzymes and muskmelon growth in the greenhouse. - Soil Research 56: 5964.

[56] Wang, J., Niu, W., Guo, L., Liu, L., Li, Y., Dyck, M. (2018b): Drip irrigation with film mulch improves soil alkaline phosphatase and phosphorus uptake. - Agricultural Water Management 201: 258-267.

[57] Wang, H., Wang, X., Bi, L., Wang, Y., Fan, J., Zhang, F., Hou, X., Cheng, M., Hu, W., Wu, L., Xiang, Y. (2019a): Multi-objective optimization of water and fertilizer 
management for potato production in sandy areas of northern China based on TOPSIS. Field Crops Research 240: 55-68.

[58] Wang, Z., Fan, B., Guo, L. (2019b): Soil salinization after long-term mulched drip irrigation poses a potential risk to agricultural sustainability. - European Journal of Soil Science 70: 20-24.

[59] Wu, X. Y., Cao, H. X., Wang, H. B. (2018): Effect of Planting Row Spacing and Irrigation Amount on Comprehensive Quality of Short-Season Cultivation Tomato in Solar Greenhouse in Northwest China. - Scientia Agricultura Sinica 51: 940-951.

[60] Xu, J. Z., Wei, Q., Peng, S. Z. (2012): Distribution characteristics of soil water under partial wetted irrigation and it is potential environmental effects. - Journal of Water Resources \& Water Engineering 26: 1-6.

[61] Yang, H., Du, T., Mao, X., Ding, R., Shukla, M. K. (2019): A comprehensive method of evaluating the impact of drought and salt stress on tomato growth and fruit quality based on EPIC growth model. - Agricultural Water Management 213: 116-127.

[62] Yu, Y., Gong, S., Xu, D., Wang, J., Ma, X. (2010): Effects of Treflan injection on winter wheat growth and root clogging of subsurface drippers. - Agricultural Water Management 97: 723-730.

[63] Zhang, X. J., Wu, Z. W., Ding, X. M., Li, X. (2009): Experimental analysis of water distribution characteristics of micro-sprinkling hose. - Transactions of the CSAE 25(4): 66-69.

[64] Zhang, H., Xiong, Y., Huang, G., Xu, X., Huang, Q. (2017): Effects of water stress on processing tomatoes yield, quality and water use efficiency with plastic mulched drip irrigation in sandy soil of the Hetao Irrigation District. - Agricultural Water Management 179: 205-214.

[65] Zhou, L., Feng, H., Zhao, Y., Qi, Z., Zhang, T., He, J., Dyck, M. (2017): Drip irrigation lateral spacing and mulching affects the wetting pattern, shoot-root regulation, and yield of maize in a sand-layered soil. - Agricultural Water Management 184: 114-123.

[66] Zhu, Y., Cai, H., Song, L., Wang, X., Shang, Z., Sun, Y. (2020): Aerated Irrigation of Different Irrigation Levels and Subsurface Dripper Depths Affects Fruit Yield, Quality and Water Use Efficiency of Greenhouse Tomato. - Sustainability 12: 270-278.

[67] Zotarelli, L., Scholberg, J. M., Dukes, M. D., Muñoz-Carpena, R., Icerman, J. (2009): Tomato yield, biomass accumulation, root distribution and irrigation water use efficiency on a sandy soil, as affected by nitrogen rate and irrigation scheduling. - Agricultural Water Management 96: 23-34. 